\title{
Product Design Choices
}

\section{Designing for Durability}

Designing and constructing superior products is expected to go hand in hand with creating products that work faster, offer greater precision, perform more functions, work more reliably, last longer, and are increasingly productive-all issues generally related to quality. Swiss SMEs lived up to many of these performance requirements. EAO's push buttons, for instance, are engineered to sustain over 10 million touches over their lifetime. In terms of benefits delivered by their product, Felco had a very special way to determine it and thus operationalize quality.

At Felco, durability was a requirement for long-term use. Felco products were made to be turned over from generations to generations rather than to be disposed of soon. To achieve durability and allow the company to issue a life-long guarantee, only the most exacting manufacturing processes and materials could be used. Company values supported the creation of the best possible pruning products. Precision in cutting, or pruning, also guaranteed "quick healing of the pruning wound" resulting in better yields for the farmers. ${ }^{1}$

In several instances, the researched companies added functionally enhanced design, or styling, that heightened their product's visual appeal. There is an additional element that comes through across our sample and, in some instances, makes the difference in a product's ultimate success-focusing on the actual end customer and how easy it is for them to use the product. This is sometimes also referred to as ergonomics. Felco's approach to ergonomics is addressed later in this chapter.

As mentioned, an important feature of the EAO push buttons is that they are engineered to sustain over 10 million touches over their lifetime. However, it was the attention the company management paid to the user that heavily influenced the company's product design concept.

\footnotetext{
${ }^{1}$ Adapted from Felco company profile. 
The EAO team proposing a new product was tasked to put five core value propositions on a single page and not to create a large book of technical specifications. The key questions to be answered were: "Who is pushing the button?" and "Why is this person pushing the button?" The user's task and the user's experience were always at the core of new products, ever since the two founding pioneers started EAO. ${ }^{2}$

\section{Designing with Flair}

Visual design is at the core of many of the B2C products which require superior design features to compensate for the higher costs of Swiss-made products. Such design superiority can be observed with Kuhn Rikon kitchen utensils and cooking pots and with Caran d'Ache pencil sets. In 2018, the Swiss government awarded Felco the Swiss Design Award for its distinctive red-handled products. With its textile products, Lantal was also using superior design to compete in its marketplace. Pictures of these products are depicted in some of the company profiles. The extent to which companies concentrate on design is best illustrated by the process undertaken at Jura and the role company management played in supporting it.

Design was at the core of Jura's strategy. The company was at the forefront of detecting a trend where coffee machines became an aspirational product for high-end customers. Modern kitchens increasingly became an open area and an attractively designed coffee machine would be part of the total look. All features of Jura machines were originated, controlled and driven by the company. Its CEO, Probst, played the leading role in this process as he frequently travelled to international sites. He was fond of visiting automobile shows and he appears to have been influenced by modern auto design features. The F90 model launched in 2000 was considered the model that most defined the design of future Jura machine generations. ${ }^{3}$

\section{Ergonomics, Broadly Defined}

The interpretation of ergonomic principles, adopted by some Swiss SMEs, is broad. It not only includes product usage but also goes all the way to include maintenance and the corresponding design for ease of maintenance. At Felco, product ergonomics was defined from the user's point of view. This perspective was clearly defined, operationalized, and then translated into a superior product, which was in competition with products a third of its price.

In vineyards, plants had to be pruned during a limited time window, with professional pruners in large vineyards performing thousands of cuts a day. As a result, Felco pruners could withstand 10,000 cuts a day without causing injury to the user's hand. Comfort in the pruner's hand, as well as having a minimum weight and a spring for effort reduction, were critical. To achieve the best ergonomics possible, Felco offered products with differently

\footnotetext{
${ }^{2}$ Adapted from EAO company profile.

${ }^{3}$ Adapted from Jura company profile.
} 
shaped handles, for different hand sizes and for left- or right-handed pruners, as well as handles that could tilt during the pruning action. ${ }^{4}$

The effectiveness of the principle of being user-friendly through ease of maintenance and operation was also demonstrated at Thermoplan, producer of fully automatic coffee machines, whose initial success came from solving a persistent problem in hotel and restaurant kitchens. In fact, the company applied the principle of ergonomics in three consecutive scenarios to propel itself into becoming a leading supplier of automated coffee machines for professional use.

Starting out in the kitchen installation business, Thermoplan's founder Domenic Steiner regularly attended industrial fairs that attracted hotel and restaurant kitchen designers and operators. During his many exchanges with other fair visitors, Steiner learned that one of the notoriously difficult elements of any restaurant kitchen was the cream whipping equipment. As he had installed many of them himself, he knew them to be bulky, difficult to clean and with kitchen operators complaining that they were often a stumbling block to pass food inspections. Clearly, whipping cold cream was a 'pain point' for restaurant and hotel owners. This made Steiner look for a team to solve the problem. Together with a local mechanical workshop, known for its tinkering mindset and skills, they solved the aeration problem and in 1983 brought a cold cream whipping device on the market half the size of existing equipment, considerably more user-friendly, easy to clean and allowed for connecting a TetraPak cream container. This simple device branded 'S'Whipper' conquered the world. Within a few years, the company was represented in 60 countries. ${ }^{5}$

The success of Thermoplan leads to two more new product ideas that were both based on the idea of simplification, ease of use, and ease of maintenance for hot milk, lattes, and cappuccino coffees.

Launched in 1993 under the brand name of 'Faomino,' Thermoplan's new equipment was designed based on the same ease of use and maintenance principles as its cold cream whipper. In a short period, Thermoplan became global market leader for automatic milk foam production as required for the ever-growing popularity of cappuccino coffees and lattes in the US. As a result of its success, Thermoplan's name became associated the world over with hot milk foam. ${ }^{6}$

From there on, it was just one more step to design and launch a fully automatic espresso machine that would operate on the ease of use principle, for example, at the push of a button, easy to maintain and include both the cold cream whipper and hot milk foamer as modules. Up to that time, espresso coffee was prepared using Italian espresso machines that required several manual steps and an experienced operator. It was the same principle of ease of use, or coffee at the push of a button, that Jura had applied earlier for its in-home espresso machines.

\footnotetext{
${ }^{4}$ Adapted from Felco company profile.

${ }^{5}$ Adapted from Thermoplan company profile.

${ }^{6}$ ibid.
} 
The principle of ease of use was further perfected by Pilatus regarding the world of ease of flying and ease of maintenance for executive and private planes. In its first 20 years of existence, Pilatus had largely produced training aircraft for military pilot training. In 1957, the company commenced the development of a small, all-metal, rugged transporter for civil use branded "Pilatus Porter PC-6." Its major differentiator was the short takeoff and landing capabilities (STOL) for operation from unpaved and rough airstrips in remote areas. The rugged airframe was designed for low maintenance. Its simple structure allowed for repairs in the field. The highly energy-absorbent undercarriage with low-pressure tires allowed the plane to operate from more rugged terrain. Capitalizing on this experience, Pilatus began design work on a new civil aviation model named PC-12.

Conceived by Pilatus as the first single-engine light plane equipped with a pressurized cabin that could seat up to nine passengers and cover distances as long as 3,500 km, the PC-12 was to turn into a major success with over 1,700 deliveries since 1994. The PC-12 retained some of the takeoff and landing capabilities of the PC- 6 with the ability to operate from unpaved airstrips. Specially designed landing gear arrangements allowed the PC-12 to utilize a large number of airfields most executive planes would be otherwise excluded from. Certified for single pilot operation, the PC-12 became the plane of choice for owner-flown executive pilots. The PC-12 was designed for ease of maintenance with the layout of the engine and other key parts easily accessible to mechanics for repair or replacement. ${ }^{7}$

Two elements stand out: first, designing the PC-12 so that it could be operated by one pilot, allowing licensed executives and business owners to fly without a professional pilot and, second, the construction allowing for ease of maintenance, reducing the operating costs on a flight-hour basis below that of other, lower-cost planes. These design principles were carried out once more into the launch of the PC-24, which was an executive jet that retained all of the elements related to ease of flying from the previous PC-12 model series. This was Pilatus' first jet engine model. The prototype made its maiden flight in 2015 , and the final certification was completed in 2017. First deliveries were made in 2018.

The Pilatus PC-24 cockpit was laid out for two pilots. The Advanced Cockpit Environment reduced the pilot workload to the extent that it allowed for single pilot certification. Single pilot certification meant that executives could use the plane for business purposes and, if certified, could use themselves and were not required to hire a professional pilot, substantially reducing hourly operating costs below competitive models. Up to that point, executive jets were typically flown by a professional flight crew of two. ${ }^{8}$

\footnotetext{
${ }^{7}$ Adapted from Pilatus company profile.

${ }^{8}$ ibid.
} 


\section{Design Thinking by Tradition}

The principles followed in the design concepts of these Swiss SMEs are deeply rooted in their operational philosophies. Modern management literature is full of references to Design Thinking as a methodology for approaching winning product design. ${ }^{9}$ Many of the Swiss SMEs in this study preceded this management concept and had adopted it long before a name for the process was created and popularized. The design ideas for Pilatus executive jets, the Thermoplan coffee machines, and the Felco pruning shears could all make excellent examples in a Design Thinking workshop offered by many consultants today. These companies institutionalized the concept of looking over the shoulders of their customers a long time ago and perfected the results to their own benefit, thus adding value to their products and achieving premium prices on global markets. They are Design Thinkers!

Open Access This chapter is licensed under the terms of the Creative Commons Attribution 4.0 International License (http://creativecommons.org/licenses/by/4.0/), which permits use, sharing, adaptation, distribution and reproduction in any medium or format, as long as you give appropriate credit to the original author(s) and the source, provide a link to the Creative Commons license and indicate if changes were made.

The images or other third party material in this chapter are included in the chapter's Creative Commons license, unless indicated otherwise in a credit line to the material. If material is not included in the chapter's Creative Commons license and your intended use is not permitted by statutory regulation or exceeds the permitted use, you will need to obtain permission directly from the copyright holder.

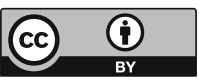

\footnotetext{
${ }^{9}$ Brown T (June 2008) Design thinking. Harvard Business Review 85-92; Brown T, Katz B (2009) Change by design: how design thinking transforms organizations and inspires innovation. Harper Business, New York.
} 